See discussions, stats, and author profiles for this publication at: https://www.researchgate.net/publication/271330147

\title{
Treatment of a suspension of PCB contaminated soil using iron nanoparticles and electric current
}

Article in Journal of Environmental Management · January 2015

Dol: 10.1016/j.jenvman.2015.01.015 · Source: PubMed

\section{CITATIONS}

11

4 authors:

A Helena I Gomes

University of Nottingham

49 PUBLICATIONS 773 CITATIONS

SEE PROFILE

Alexandra B. Ribeiro

Universidade NOVA de Lisboa

146 PUBLICATIONS 2,320 CITATIONS

SEE PROFILE
151

Lisbeth M Ottosen

Technical University of Denmark

234 PUBLICATIONS 3,524 CITATIONS

SEE PROFILE

Celia Dias-Ferreira

Instituto Politécnico de Coimbra

99 PUBLICATIONS 1,052 CITATIONS

SEE PROFILE

Some of the authors of this publication are also working on these related projects:

Project R3AW - Resource Recovery and Remediation of Alkaline Wastes View project

ion transport in porous materials View project 


\section{Treatment of a suspension of PCB contaminated soil using iron nanoparticles and electric current}

Helena I. Gomes ${ }^{1,2}$, Lisbeth M. Ottosen ${ }^{3}$, Alexandra B. Ribeiro ${ }^{1}$, Celia Dias-Ferreira ${ }^{2}$

${ }^{1}$ CENSE, Departamento de Ciências e Engenharia do Ambiente, Faculdade de Ciências e Tecnologia, Universidade Nova de Lisboa, 2829-516 Caparica, Portugal

${ }^{2}$ CERNAS - Research Center for Natural Resources, Environment and Society, Escola Superior Agraria de Coimbra, Instituto Politecnico de Coimbra, Bencanta, 3045-601

Coimbra, Portugal

${ }^{3}$ Department of Civil Engineering, Technical University of Denmark, Brovej, Building 118, DK 2800 Kgs. Lyngby, Denmark

* Corresponding author. Tel. +351 212948300, Fax. +351 212948554. E-mail address:

hrg@campus.fct.unl.pt (Helena I. Gomes) 


\section{ABSTRACT}

Contaminated soils and sediments with polychlorinated biphenyls (PCB) are an important environmental problem due to the persistence of these synthetic aromatic compounds and to the lack of a cost-effective and sustainable remediation technology. Recently, a new experimental setup has been proposed using electrodialytic remediation and iron nanoparticles. The current work compares the performance of this new setup (A) with conventional electrokinetics (setup B). An historically contaminated soil with an initial PCB concentration of $258 \mu \mathrm{g} \mathrm{kg}$ was treated during 5, 10, 20 and $45 \mathrm{~d}$ using different amounts of iron nanoparticles in both setups A and B. A PCB removal of $83 \%$ was obtained in setup A compared with $58 \%$ of setup B. Setup A also showed additional advantages, such as a higher PCB dechlorination, in a shorter time, with lower nZVI consumption, and with the use of half of the voltage gradient when compared with the traditional setup (B). Energy and nZVI costs for a full-scale reactor are estimated at $72 €$ for each cubic meter of PCB contaminated soil treated on-site, making this technology competitive when compared with average off-site incineration $\left(885 € \mathrm{~m}^{3}\right)$ or landfilling $\left(231 € \mathrm{~m}^{3}\right)$ cost in Europe and in the USA (327 USD $\left.\mathrm{m}^{3}\right)$. 


\section{Highlights}

- High PCB removal (83\%) was achieved with the new electrodialytic setup.

- Short times and less nanoparticles were needed using the new electrodialytic setup.

- Hepta and hexa chlorinated congeners were also degraded.

- Direct current enhanced dechlorination in the conventional setup through $\mathrm{pH}$ change.

- The new setup is competitive compared with incineration and landfilling.

\section{Keywords}

Electrokinetics (EK); electrodialytic remediation (EDR); nZVI; polychlorinated biphenyls; PCB 


\section{INTRODUCTION}

Polychlorinated biphenyls (PCB) are a family of 209 congeners, classified as persistent organic pollutants (POP), carcinogenic and recalcitrant, which strongly adsorb to soils and sediments. Despite the environmental concern regarding PCB ecotoxicity and accumulation in the food chain, there is no quantification of the total volumes of PCB contaminated soils and sediments worldwide. A review of remediation technologies available for PCB-contaminated soils and sediments identified the need to find cost-effective and more sustainable alternatives than the commonly adopted "dig and dump" and "dig and incinerate" solutions (Gomes et al., 2013a).

Electroremediation comprises a group of technologies that has evolved over the last decades with the incorporation of enhancement techniques and the combination with other remediation technologies, targeting a wide range of contaminants. Electrodialytic remediation - a method based on the combination of the electrokinetic movement of ions in soil with the principle of electrodialysis - was used successfully in different matrices such as mine tailings (Hansen et al., 2007), soils ex situ (Ottosen et al., 2009b), different types of fly ashes (Ferreira et al., 2005; 2008), wood waste (Ribeiro et al., 2000), sewage sludge (Pazos et al., 2010), freshwater sediments and harbor sediments (Kirkelund et al., 2009). Electrodialytic remediation of suspended soil has proven to be a faster process to be used ex situ for the removal of heavy metals (Ottosen et al., 2013; Sun et al., 2012) and polycyclic aromatic hydrocarbons (PAH) (Lima et al., 2012).

Zero valent iron nanoparticles (nZVI) were considered a promising alternative for PCB dechlorination in aqueous solutions (He et al., 2010; Lowry and Johnson, 2004; Wang and Zhang, 1997; Zhuang et al., 2011). In general, the dechlorination can be expressed by the following reaction (Zhang et al., 1998): 


$$
\mathrm{C}_{\mathrm{x}} \mathrm{H}_{y} \mathrm{Cl}_{2}+\mathrm{zH}+\mathrm{zFe}^{0} \rightarrow \mathrm{C}_{\mathrm{x}} \mathrm{H}_{y+z}+\mathrm{zFe}^{2+}+\mathrm{zCl}
$$

in which iron acts as a reductant (electron donor) for the removal of chlorine. This reaction is similar to the process occurring during iron corrosion, with the beneficial effects of transforming chlorinated pollutants. Still a 95\% PCB dechlorination in soils was just achieved at high temperatures $\left(300{ }^{\circ} \mathrm{C}\right)$ (Varanasi et al., 2007) and a removal efficiency of $98 \%$ with $100 \mathrm{mg}$ of nZVI was obtained at $600{ }^{\circ} \mathrm{C}$ (Liu et al., 2014). In field applications, nZVI can be injected in the aquifers through injection wells, or incorporated to topsoil to adsorb or degrade pollutants (Crane and Scott, 2012). Results in aquifers show that nZVI have limited mobility, ranging from $1 \mathrm{~m}$ (Kocur et al., 2014) to 6-10 m (Zhang and Elliott, 2006).

One of the methods tested to enhance nZVI mobility was the use of low-level direct current (DC) (Jones et al., 2010; Pamukcu et al., 2008; Yang et al., 2007), using the same principles of electrokinetic remediation (EKR). Electroremediation and nZVI were combined by Fan et al (2013) and they obtained a 20\% PCB removal from soils after $14 \mathrm{~d}$ using $\mathrm{Fe} / \mathrm{Pd}$ bimetallic nanoparticles in conjunction with surfactants.

In a recent work (Gomes et al., 2014a), we presented a new experimental setup for on-site or ex-situ electrokinetic treatment of PCB contaminated soils in which the soil is kept in suspension with the simultaneous addition of nZVI and surfactants (saponin and Tween 80). In the current work the main objectives were to: i) assess the effectiveness for the dechlorination of PCB by nZVI of the new setup in comparison with the traditional cell used in electrokinetic setups; ii) test if longer EKR experiments with nZVI could increase PCB dechlorination; and to iii) evaluate the effect of using direct electric current 


\section{MATERIALS AND METHODS}

\subsection{Chemicals and solvents}

PCB standards were analytical grade, obtained from Fluka, Sigma-Aldrich (PCB28, 52, 101, 138, 153, 180 and 209) and Ultrascientific (PCB30; PCB65 and PCB204). The solvents hexane and acetone were Pestinorm (VWR BDH Prolabo). Hydrochloric (37.6\%), nitric $(65 \%)$ and sulfuric $(95-7 \%)$ acids were trace metal grade. Anhydrous $\mathrm{Na}_{2} \mathrm{SO}_{4}, \mathrm{KMnO}_{4}$, $\mathrm{NaCl}$, and silica gel (silicic acid) were lab grade. Silica gel was cleaned up before use according to the USEPA method 3630C. The water was deionized with a Milli-Q plus system from Millipore (Bedford, MA, USA). A polyacrylic acid (PAA) slurry-stabilized suspension of zero valent iron nanoparticles (NANOFER 25S, NANO IRON, s.r.o., Rajhrad, Czech Republic) was used in the experiments, with $50 \mathrm{~nm}$ average particles size, an average surface area of 20-25 $\mathrm{m}^{2} \mathrm{~g}^{-1}$, a particle size distribution of 20-100 $\mathrm{nm}$ and iron content in the range of 80-90 wt. \%.

\subsection{Soil characterization}

The contaminated soil used in the experiments was provided by a hazardous waste operator in Portugal and is a mixture of contaminated soils from industrial sites with transformers oils spills. The soil characterization methods used were described in Jensen et al (2007). The elemental analysis were made using Inductively Coupled Plasma-Atomic Emission Spectrometer (ICP) on an Agilent ICP-OES Varian 720-ES equipment. Table 1 presents the physical and chemical characteristics of the soil used in the experiments. According to the United States Department of Agriculture Natural Resources Conservation Service, this soil is classified as "very strongly alkaline" and this alkaline $\mathrm{pH}$ can be due to the presence of strong basis of industrial origin. The soil tested is a mixture of industrial contaminated soils, so it is also possible to have in the mixture fly ashes from coal fired boilers or power plants, rich in calcium oxide $(\mathrm{CaO})$, which readily dissolves in water to form 
$\mathrm{Ca}(\mathrm{OH})_{2}$ (Lopareva-Pohu et al., 2011). The PCB concentrations measured are above the guidance values for total PCB in Denmark, even though only the most common congeners in environmental samples were measured. In Denmark, the limit for soil quality is $0.02 \mathrm{mg} \mathrm{kg-1}$ total PCB and if the concentration exceeds $50 \mathrm{mg} \mathrm{kg}^{-1}$ the soil is classified as hazardous waste (Jensen, 2009). The soil was homogenized, air dried and sieved, and only the particles with size $<2 \mathrm{~mm}$ were used in the experiments.

Table 1. Physical and chemical characteristics of the soil.

\begin{tabular}{|c|c|}
\hline \multicolumn{2}{|l|}{ Parameter } \\
\hline \multicolumn{2}{|l|}{ Soil particles $(\%)$} \\
\hline Coarse sand $(200<\varnothing<2000 \mu \mathrm{m})$ & 19.1 \\
\hline Fine sand $(20<\varnothing<200 \mu \mathrm{m})$ & 67.3 \\
\hline Silt $(2<\varnothing<20 \mu \mathrm{m})$ & 12.7 \\
\hline Clay $(\varnothing<2 \mu \mathrm{m})$ & 0.9 \\
\hline Textural classification & Loamy sand \\
\hline $\mathrm{pH}\left(\mathrm{H}_{2} \mathrm{O}\right)$ & 12.2 \\
\hline Conductivity ( $\mathrm{mS} \mathrm{cm} \mathrm{cm}^{-1}$ & 18.76 \\
\hline \multicolumn{2}{|l|}{ Exchangeable cations $\left(\mathrm{cmol}_{(0)} \mathrm{kg}^{-1}\right)$} \\
\hline $\mathrm{Ca}^{2+}$ & 83.75 \\
\hline $\mathrm{Mg}^{2+}$ & 3.2 \\
\hline $\mathrm{K}^{+}$ & 26.88 \\
\hline $\mathrm{Na}^{+}$ & 9.37 \\
\hline Sum of exchangeable cations $\left(\mathrm{cmol}_{(\mathrm{c})} \mathrm{kg}^{-1}\right)$ & 123.2 \\
\hline Calcium carbonate $(\%)$ & 18.0 \\
\hline Organic matter $(\%)$ & 16.46 \\
\hline Total PCBa $\left(\mu \mathrm{g} \mathrm{kg}^{-1}\right)$ & $258 \pm 24$ \\
\hline \multicolumn{2}{|l|}{$\operatorname{Metals}^{\mathrm{b}}\left(\mathrm{mg} \mathrm{kg} \mathrm{kg}^{-1}\right)$} \\
\hline Al & $20980 \pm 590$ \\
\hline As & $8.6 \pm 2.0$ \\
\hline $\mathrm{Cd}$ & $0.68 \pm 0.14$ \\
\hline $\mathrm{Cr}$ & $51.66 \pm 2.69$ \\
\hline $\mathrm{Cu}$ & $141.73 \pm 94.62$ \\
\hline $\mathrm{Fe}$ & $13162 \pm 301$ \\
\hline $\mathrm{Ni}$ & $31.98 \pm 1.26$ \\
\hline $\mathrm{Pb}$ & $45.43 \pm 3.31$ \\
\hline $\mathrm{Zn}$ & $2155 \pm 40$ \\
\hline
\end{tabular}




\subsection{PCB analysis}

For PCB analysis, the soil extraction method used was the USEPA method 3550C, in which $10 \mathrm{~g}$ of soil was extracted with $3 \times 30 \mathrm{~mL}$ of acetone-hexane (1:1) in a glass vial by ultrasonication $(20 \mathrm{kHz})$ for $60 \mathrm{~min}$. After vacuum filtration and concentration, the extracts were cleaned following the USEPA methods 3665A and 3630C. Aqueous samples (soil filtrate and catholyte) were extracted according to the method used by Lowry and Johnson (2004), after adjusting the $\mathrm{pH}$ of the acid samples to $\mathrm{pH} 7$ with $\mathrm{NaOH}$. The PCB congeners were analyzed by gas chromatography (GC) with an ECD detector (HP 6890 Series, HewlettPackard, Palo Alto, California, USA). The column used was a TRB-5-MS with $30 \mathrm{~m} \times 0.25$ $\mathrm{mm}$ i.d. and $0.25 \mu \mathrm{m}$ film thickness (Phenomenex, Torrance, CA, USA). The oven temperature was programmed starting at $70{ }^{\circ} \mathrm{C}$ for $2 \mathrm{~min}$, increased to $150{ }^{\circ} \mathrm{C}$ at a rate of $25{ }^{\circ} \mathrm{C} \mathrm{min}{ }^{-1}$ and then increased $4{ }^{\circ} \mathrm{C} \mathrm{min}^{-1}$ to $200{ }^{\circ} \mathrm{C}, 8{ }^{\circ} \mathrm{C} \mathrm{min}{ }^{-1}$ to $280{ }^{\circ} \mathrm{C}$ where it holds for 4 min and finally $10{ }^{\circ} \mathrm{C} \mathrm{min}^{-1}$ to $300{ }^{\circ} \mathrm{C}$, where it holds for $2 \mathrm{~min}$. Pure nitrogen was used as the carrier gas. The injector was splitless set at $260^{\circ} \mathrm{C}$. The injections of $1.00 \mu 1$ were performed manually.

\subsection{Electroremediation experiments}

The electroremediation experiments were carried out in two different cylindrical Plexiglas-cells. The electrodialytic cell (setup A) had two compartments [Figure 1 a)]. In one compartment $(\mathrm{L}=10 \mathrm{~cm}, \varnothing=8 \mathrm{~cm})$ the anode was placed directly into the soil slurry and the plastic-flaps attached to a glass-stick overhead stirrer (Lab-egg Bie\&Bernsten, Denmark, $\sim 350 \mathrm{rpm}$ ) maintained the soil in suspension during the treatment. A cation-exchange membrane (CAT, GE Water \& Process Technologies Bvba - ED, Cation, CR67, MKIII, Blank) separates this compartment from the cathode compartment $(\mathrm{L}=5 \mathrm{~cm}, \varnothing=8 \mathrm{~cm})$ [Figure $1 \mathrm{~b}$ )]. The catholyte was recirculated by a mechanical pump (Plastomec magnet pump, model P05) between the chamber and a glass bottle. 


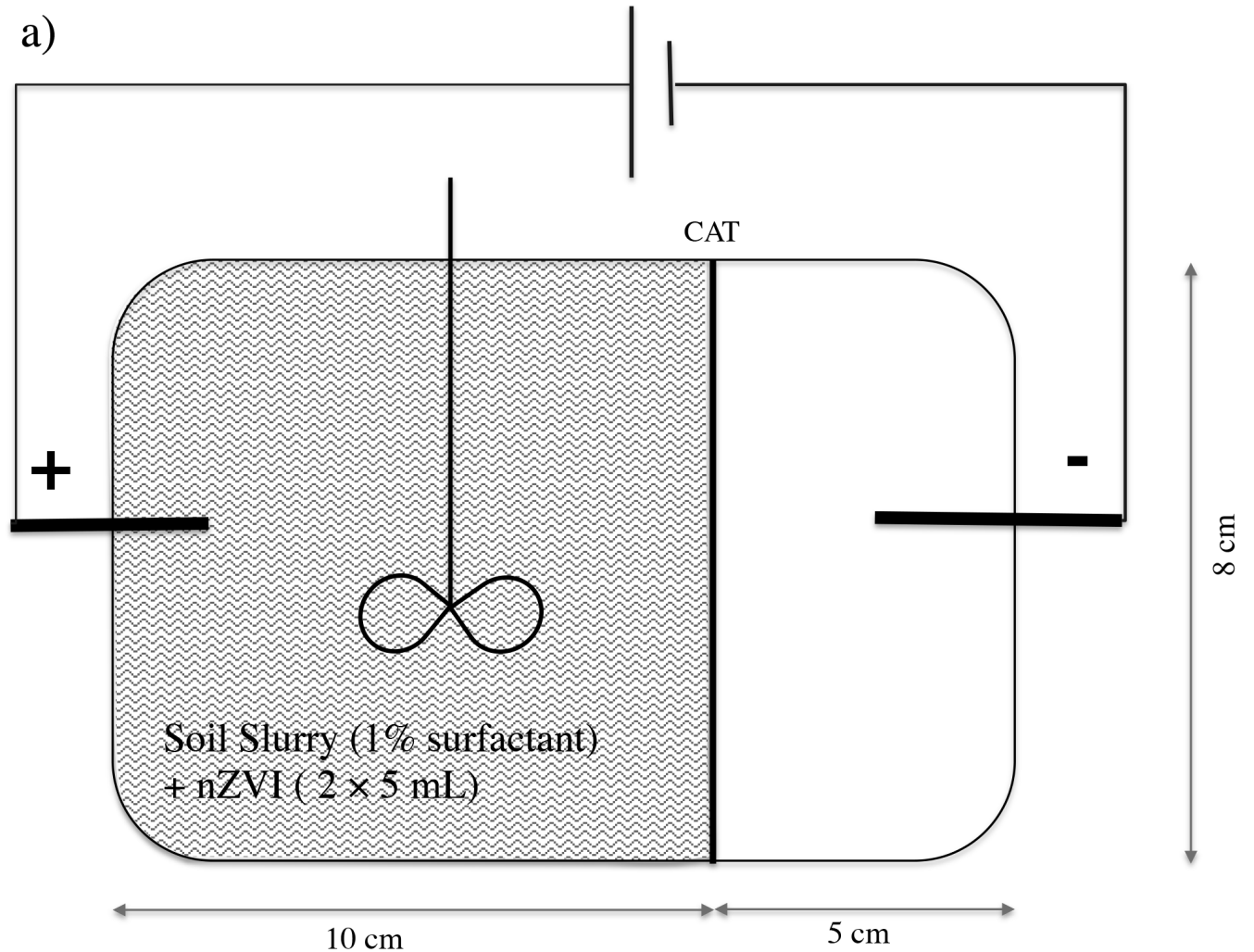

b)

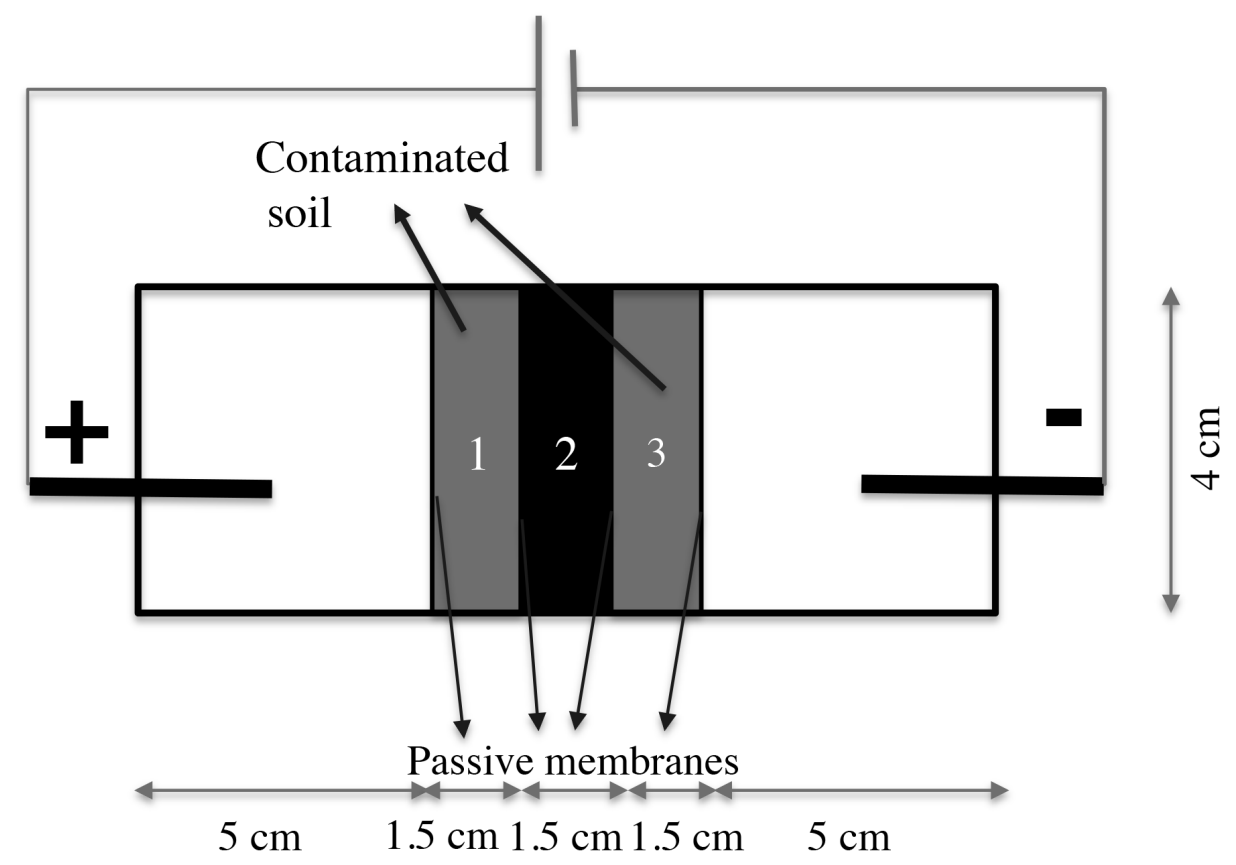

Figure 1. Schematic representation of the experimental setups used in the experiments: a) setup A - new electrodialytic cell (CAT - cation exchange membrane); b) electrokinetic cell (setup B). 
The electrokinetic cell (setup B) consists of three compartments: two electrode compartments $(\mathrm{L}=5 \mathrm{~cm}$, internal diameter $\varnothing=4 \mathrm{~cm})$ and a central compartment. The central compartment subdivided in three parts $(\mathrm{L}=1.5 \mathrm{~cm}$ each, total of $4.5 \mathrm{~cm}, \varnothing=4 \mathrm{~cm})$. The nZVI were placed in the middle part (2) and the soil in the other two [1 and 3, Figure $1 \mathrm{~b}$ )]. The soil was saturated with deionized water before the experiments. Cellulose filters (passive membranes) were used to assure the separation between the soil and electrolytes, and the soil and the iron nanoparticles.

In both setups, a power supply (Hewlett Packard E3612A, Palo Alto, USA) was used to maintain a constant voltage and the current was monitored (Fluke 179 multimeter). The electrodes were platinized titanium bars, with a diameter of $3 \mathrm{~mm}$ and a length of $10 \mathrm{~cm}$ in setup A and $5 \mathrm{~cm}$ in setup B (Permascand®).

Six different laboratory experiments (A-F) were carried out, according to the experimental conditions presented in Table 2, in order to compare the two setups and to evaluate the effect of a variable duration in setup B (as the maximum duration of the experiments in the literature was $14 \mathrm{~d}$ (Fan et al., 2013)). The iron nanoparticles were placed in the center of both cells. In setup B (experiments A, B, C and D), the central reservoir was filled at the beginning of the experiments with nZVI. In experiment $\mathrm{C}$ more $\mathrm{nZVI}$ was added ( $2 \mathrm{~mL}$ ), in days 7 and 9, to test if the addition of fresh nanoparticles could enhance the PCB dechlorination. In setup A (experiments $\mathrm{E}$ and $\mathrm{F}$ ), two injections of $5 \mathrm{~mL}$ nZVI were made at 24 and $48 \mathrm{~h}$, when the soil suspension $\mathrm{pH}$ was neutral. The electrolyte used in all experiments was $10^{-2} \mathrm{M} \mathrm{NaCl}$. In the electrodialytic setup (experiment F), the catholyte $\mathrm{pH}$ was manually maintained approximately at 2 by the periodic addition of $\mathrm{HCl} 5 \mathrm{M}$ to avoid alkaline $\mathrm{pH}$ in the catholyte. 
Table 2. Summary of experimental conditions.

\begin{tabular}{cclcccc}
\hline Exp. & $\begin{array}{c}\text { nZVI } \\
(\mathbf{m L})\end{array}$ & \multicolumn{1}{c}{ Type of injection } & Setup & $\begin{array}{c}\text { Voltage } \\
(\mathbf{V ~ c m})\end{array}$ & $\begin{array}{c}\text { Soil (g, dry } \\
\text { weight })\end{array}$ & $\begin{array}{c}\text { Duration } \\
(\mathbf{d})\end{array}$ \\
\hline A & 13 & $\begin{array}{l}\text { Unique (in the beginning of } \\
\text { experiment) }\end{array}$ & B & 2 & 65.30 & 10 \\
B & $13 \quad \begin{array}{l}\text { Unique (in the beginning of } \\
\text { experiment) }\end{array}$ & B & 0 & 49.84 & 10 \\
C & 20 & $\begin{array}{l}\text { Repeated (additional iron in } \\
\text { days 7 and 9) }\end{array}$ & B & 2 & 67.50 & 20 \\
D & 13 & $\begin{array}{l}\text { Unique (in the beginning of } \\
\text { experiment) }\end{array}$ & B & 2 & 69.94 & 45 \\
E & 10 & $\begin{array}{l}\text { 2 injections of 5 mL at 24 and } \\
48 \text { h }\end{array}$ & A & 0 & 50.01 & 5 \\
F & 10 & $\begin{array}{l}2 \text { injections of 5 } \mathrm{mL} \text { at 24 and } \\
48 \mathrm{~h}\end{array}$ & A & 1 & 50.05 & 5 \\
\hline
\end{tabular}

The current between electrodes, the soil suspension $\mathrm{pH}$ and in the electrolytes were measured every $24 \mathrm{~h}$. In setup A at the end of the experiments, the suspension from the central compartment was filtered by gravity through $0.45 \mu \mathrm{m}$ filter paper. In setup B samples from the anode and the cathode side were collected separately. Subsamples were prepared for humidity measurements. For both setups, the soil was air-dried and crushed slightly in a mortar before the PCB extraction and $\mathrm{pH}$ measurements. At the end of the experiments the Fe contents in the different parts of the cell (membranes, soil, solutions, and electrodes) were determined. The Fe contents in the CAT membranes and at the electrodes were measured after extraction in $1 \mathrm{M} \mathrm{HNO}_{3}$ and $5 \mathrm{M} \mathrm{HNO}_{3}$, respectively. The Fe was extracted from soil by the sodium dithionite-citrate-bicarbonate method (Mehra and Jackson, 1960) and from the passive membranes with concentrated $\mathrm{HCl}$.

\section{RESULTS AND DISCUSSION}

\subsection{Comparison between the two experimental setups}

Setup A shows PCB removal percentages of $83 \%$ with direct current and $29 \%$ without, as shown in Figure 2. The best removals are higher than in previous studies with conventional electrokinetics (Fan et al., 2013), higher than batch tests without current (Chen 
et al., 2014), and also higher than in previous experiments using this setup with different surfactants (Gomes et al., 2014a). The suspension and stirring of the soil enhances the PCB dechlorination by nZVI, probably due to an increase in desorption from soil and/or to a higher contact and reaction between nZVI and PCB. In the traditional electrokinetic setup (setup B), the iron has to be transported across the compacted saturated soil to reach the contaminants. Even a low proportion of carbonate minerals may cause an increase in the deposition of PAA-nZVI particles and aggregates, due to a weaker negative surface charge (Laumann et al., 2013). As the soil used in the experiments has high carbonate content (18\%), the limited dechlorination (12-58\%) observed in setup B (Figure 2) can be due to this soil characteristic. 


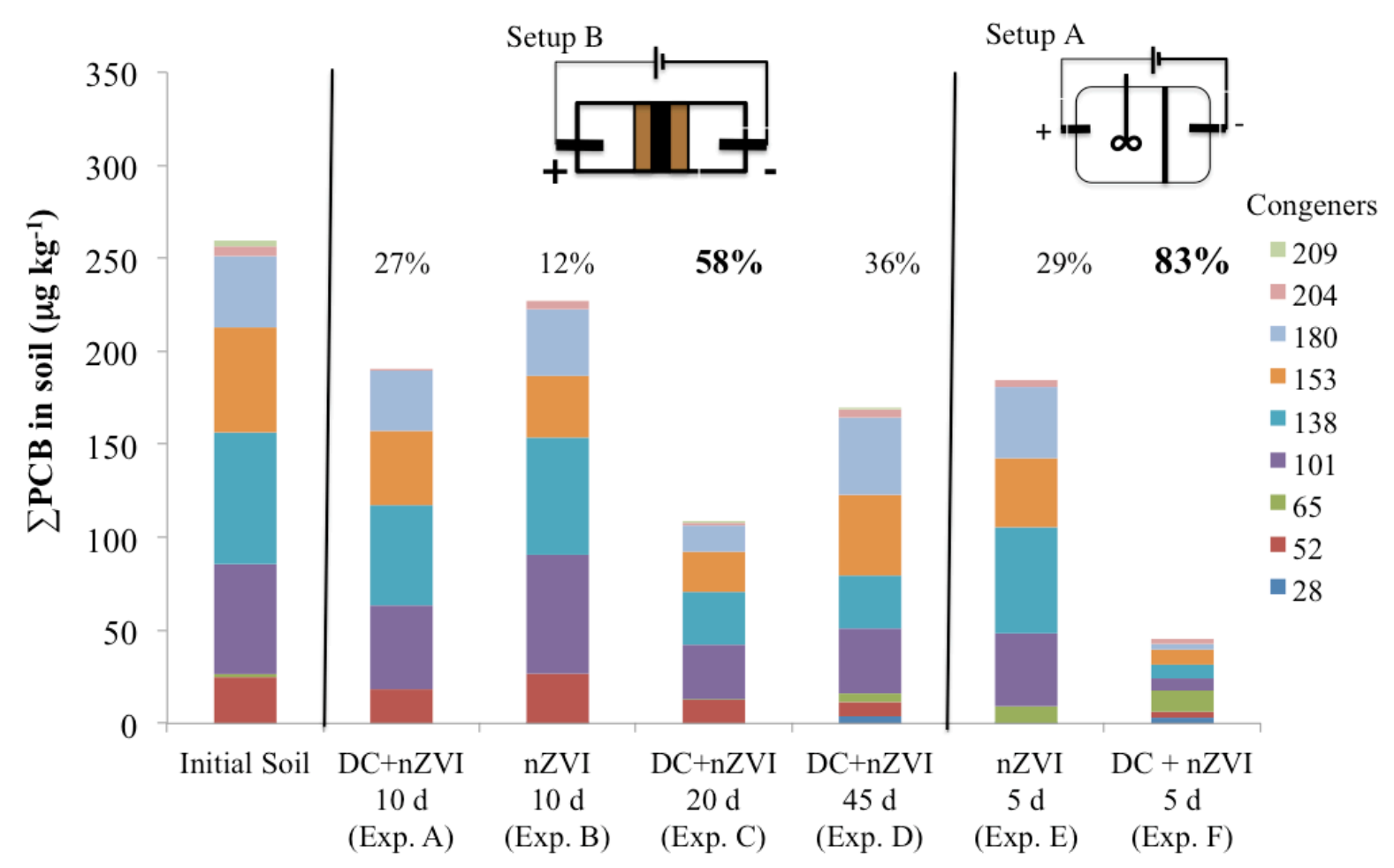

Figure 2. Average concentration of the sum of PCB congeners (PCB28, 52, 65, 101, 138, 153, 180, 204 and 209) in soil before and after the experiments using conventional electrokinetics (setup B) and the new electrodialytic setup (A). Percentages on the top of each column represent PCB removal regarding the sum of congeners analyzed in the initial soil. PCB - polychlorinated biphenyls, DC - Direct Current, nZVI - zero valent iron nanoparticles. 
In both setups, there are chemical reactions that deplete the $\mathrm{Fe}^{\circ}$ reductant power (Tosco et al., 2014; Zhang, 2003) and are occurring in the cell center compartment due to the presence of water, oxygen, $\mathrm{H}^{+}$from water electrolysis, and carbonates from the soil:

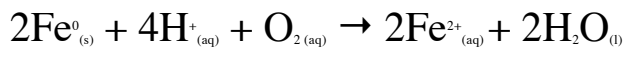

$$
\begin{aligned}
& \mathrm{Fe}^{0}{ }_{(s)}+2 \mathrm{H}_{2} \mathrm{O}_{(1)} \rightarrow \mathrm{Fe}^{2+(a y)}+\mathrm{H}_{2(8)}+2 \mathrm{OH}_{(\mathrm{as})} \\
& \mathrm{Fe}^{2+{ }_{(\mathrm{aq})}}+\mathrm{CO}_{3^{2}{ }_{(\mathrm{aq})}}^{2} \rightarrow \mathrm{FeCO}_{3(\mathrm{~s})}
\end{aligned}
$$

Also, the presence of transformer oil was found to adversely affect the PCB degradation (Chang et al., 2010). Despite the introduction of $\mathrm{H}^{+}$(resultant of hydrolysis in the anode) and the atmospheric $\mathrm{O}_{2}$ dissolved by the slurry stirring that promotes $\mathrm{Fe}^{\circ}$ oxidation, a higher PCB removal is obtained in the electrodialytic setup (A) compared with the conventional eletrokinetic setup (B). In both setups, in none of the aqueous samples (electrolyte and filtrates) PCB were detected. The electrokinetic setup (B) is more prone to nZVI aggregation and settling, as other experiments with molinate contaminated soils showed (Gomes et al., 2014c).

In other remediation techniques (Beckingham and Ghosh, 2011; Li et al., 2013; Vasilyeva et al., 2010; Wu et al., 2012), lower chlorinated congeners (tri and tetrachlorobiphenyls) were the ones with highest removal. In this study, lower chlorinated congeners were degraded, namely PCB28, PCB52 and PCB65 (particularly in setup B), but higher chlorinated congeners were also degraded (Experiment F). In some experiments an increase of PCB65 occurred (two, five and six times more the initial amount in the experiments D, E and F, respectively) likely due to the dechlorination of higher chlorinated congeners, such as PCB204. In setup B removal percentages for each congener are lower than in setup A. The dechlorination pathways of congeners by nZVI were proposed by Chen et al. (2014) for PCB153 and by Gomes et al (2014a) for PCB138 and PCB180. 


\subsection{Different duration experiments}

The experiments using the conventional electrokinetic setup (B) had different durations to assess if longer times would increase PCB dechlorination. Comparing the $10 \mathrm{~d}$ experiment (A) with the $45 \mathrm{~d}$ experiment (D), the PCB removal has a small increase (27\% vs. 36\%) (Figure 2). Although the removal percentages are higher than in previous studies with $14 \mathrm{~d}$ experiments (Fan et al., 2013), their values are not encouraging for a scale up of the process (pilot and full scale) for the remediation of PCB contaminated soils and sediments. The higher dechlorination in experiment $\mathrm{C}$ is related with the additional nZVI injected at days 7 and 9, not with the exposure duration. Comparing the congeners concentrations obtained in the soil (duplicate samples), we observed that they are not statistically different in the three experiments (A, C and D) at a 0.05 level of significance [one-way ANOVA, F(2,20) $=2.14, \mathrm{p}=0.14]$. This means that PCB dechlorination in setup B does not increase over time.

\subsection{Experiments with and without direct current}

Direct current can be used to enhance nZVI transport in different porous matrices or model soils (Gomes et al., 2013b) but, in the electrodialytic setup (A), the contact between the nanoparticles and the contaminated soil is ensured by the stirring so the current may not be needed for PCB dechlorination. However, results show that the experiment with direct current (exp. F) had a much higher PCB removal (83\%) than the experiment just with the iron nanoparticles (exp. E) (29\%). We believe that due to the high pH and buffer capacity of the soil (Table 1 and Figure 3) in the experiment without current (exp. E) the soil kept a constant alkaline $\mathrm{pH}$ that promoted the passivation of the iron nanoparticles. On the contrary, in the experiment with current (exp. F) water electrolysis (eq. 5 and 6) produces $\mathrm{H}^{+}$in the anode, thus lowering the $\mathrm{pH}$ of the soil slurry

$$
2 \mathrm{H}_{2} \mathrm{O}-4 \mathrm{e} \rightarrow \mathrm{O}_{2(3)}+4 \mathrm{H}^{+} \quad \mathrm{E}_{0}=-1.229 \mathrm{~V} \text { (anode) }
$$


$2 \mathrm{H}_{2} \mathrm{O}+2 \mathrm{e} \rightarrow \mathrm{H}_{2(8)}+2 \mathrm{OH} \quad \mathrm{E}_{0}=-0.828 \mathrm{~V}$ (cathode)

A slightly acidic $\mathrm{pH}(4.90-5.10)$ increases the dechlorination of PCB by nZVI and nZVI/Pd (Wang et al., 2012). The effect of the acidification of the soil slurry favors the PCB dechlorination when a direct current is used, explaining the higher removals obtained in exp. F compared with exp. E. Table 4 shows the $\mathrm{pH}$ values after the experiments. Only in experiment $\mathrm{F}$ a lower $\mathrm{pH}$ is obtained due to the high buffer capacity of the soil.

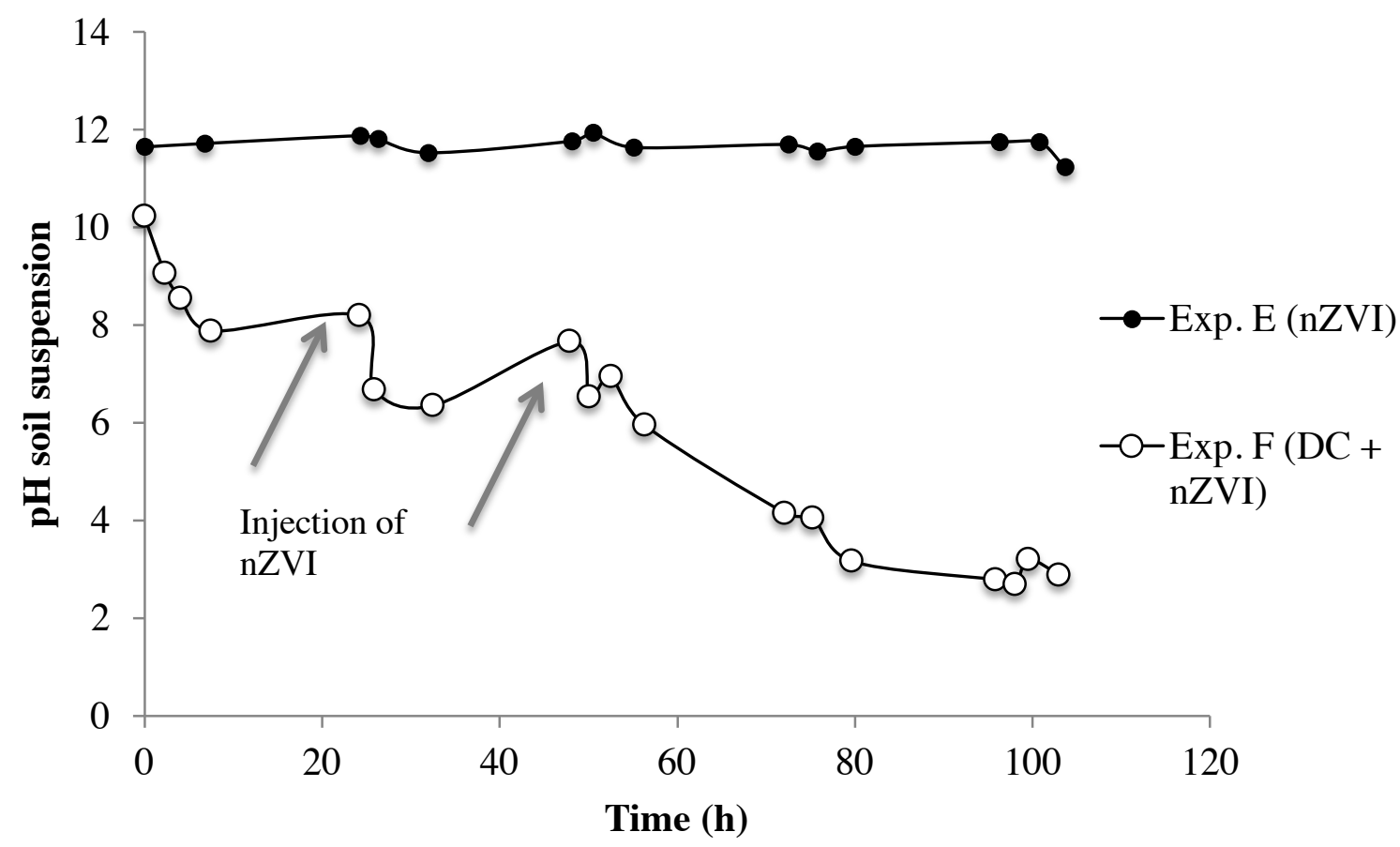

Figure 3. Evolution of $\mathrm{pH}$ in the soil suspension during the experiments using the new electrodialytic setup (A). DC - direct current, nZVI - zero valent iron nanoparticles.

Table 4. Soil pH at the end of the experiments in both setups. Initial soil $\mathrm{pH}$ is 12.2.

\begin{tabular}{ccccc}
\hline \multicolumn{2}{c}{ Setup A } & & \multicolumn{2}{c}{ Setup B } \\
Exp. & Soil pH & Exp. & Anode side & Cathode side \\
\hline & & A & 11.28 & 12.18 \\
E & 9.47 & B & 12.25 & 12.07 \\
F & 5.70 & C & 11.60 & 11.83 \\
& & D & 11.21 & 11.69 \\
\hline
\end{tabular}


Figure 4 shows the current values measured in the experiments, using both cells. The highest current values were measured in setup A and are related to the high metal content of the tested soil. When the metals are dissolved or desorbed by the $\mathrm{H}^{+}$generated at the anode, the conductivity of the suspension increases. In setup B (Figure 4), the current values reached a peak immediately after the experiment start, when the quantity of ions in the pore solution was higher due to the dissolution of salts associated with soil particles. The current dropped abruptly in the first hours and stabilized thereafter, with little oscillations, in all experiments. The $\mathrm{H}^{+}$generated at the anode can solubilize transition metals such as $\mathrm{Fe}$ and $\mathrm{Ni}$ from soil, that can degrade PCB via catalytic hydrodechlorination with $\mathrm{H}_{2}$ successively removing chlorine atoms from PCB generating biphenyl, according to the general chemical equation (Wu et al., 2012):

$$
\mathrm{C}_{12} \mathrm{H}_{(10 \cdot \mathrm{m})} \mathrm{Cl}_{\mathrm{m}}+\mathrm{nH}_{2} \rightarrow \mathrm{C}_{12} \mathrm{H}_{(10-m+\mathrm{m} n \mathrm{n}} \mathrm{Cl}_{\mathrm{m} \cdot \mathrm{n}}+\mathrm{nHCl}, \mathrm{m} \geqq \mathrm{n}
$$

Although this hydrodechlorination has been reported for aqueous or organic solvents, in the tested setup there are all the needed conditions for it to occur. However, further research is needed to evaluate the importance of this dechlorination process, to assess how iron (natural and manufactured) and other metals act as catalysts. 

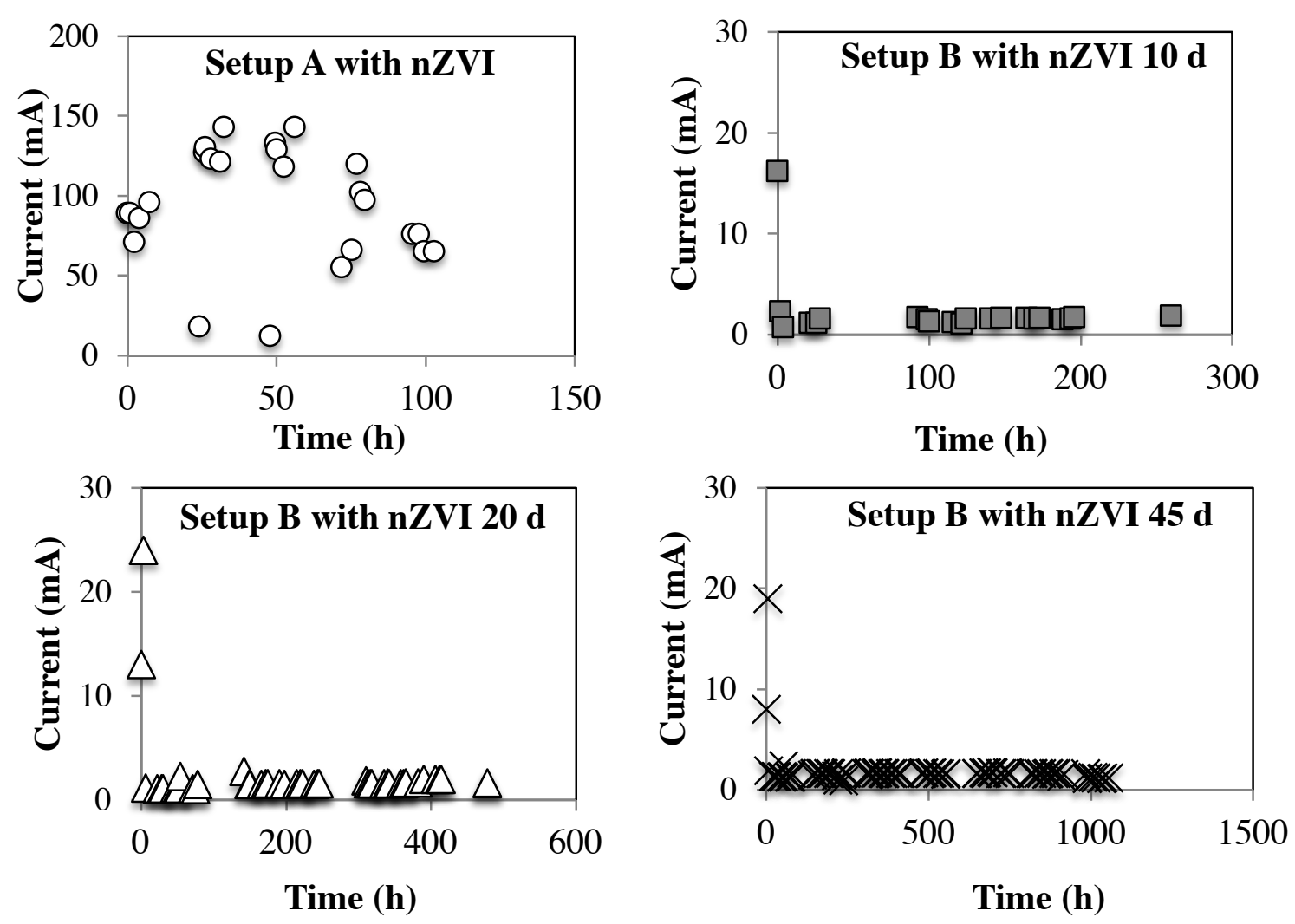

Figure 4. Current variation during the experiments.

\subsection{Upscale of the new electrodialytic setup (A)}

Based on the preliminary results obtained in this work, a rough estimate of the operation cost of using the new electrodialytic setup (A) for ex situ remediation of PCB contaminated soil was made. Basically, considering the energy consumption for the stirring and electrodialytic remediation of a full-scale reactor for a cubic meter of contaminated soil and the nZVI costs (at current commercial prices $61 € \mathrm{~kg}^{-1}$ ), the costs are $72 €$. The energy consumption was extrapolated from the lab scale cell $\left(0.88 \mathrm{Wh}^{-1}\right)$. For the calculation of the energy costs, we considered the average cost of energy in the European Union (EUROSTAT 2011). If we are only dealing with organic contaminants that can be completely degraded, there is no need to treat and dispose the anolyte after separation from the solids. Even adding the excavation and transport costs, this solution is competitive when compared with the off- 
site incineration average costs $\left(885 € \mathrm{~m}^{3}\right)$ and off-site landfilling costs $\left(231 € \mathrm{~m}^{3}\right)$ in Europe (Summersgill, 2006) and the off-site landfilling costs for hazardous waste in the USA (327 USD m ${ }^{3}$, approximately $\left.239 € \mathrm{~m}^{3}\right)$ (Ram et al., 2013).

\section{CONCLUSIONS}

In summary, the new electrodialytic setup tested in this work allowed PCB dechlorination from contaminated soil ex situ at a higher percentage, in a shorter time, with lower nZVI consumption, and with the use of half of the voltage gradient when compared with the traditional electrokinetic setup. In addition, there is no need to treat and dispose of the anolyte. However, additional testing with different soils, repeated application of the technique on the same material (also with different duration experiments), testing of enhancement methods and further optimization and scale up of the process are needed to prove the versatility of the electrodialytic setup.

The results show that the soil characteristics are important and affect the reactions between nZVI and the target contaminant, especially $\mathrm{pH}$ and carbonate content. Direct current can enhance dechlorination in this new electrodialytic setup.

\section{ACKNOWLEDGMENTS}

This work was funded by the European Regional Development Fund (ERDF) through COMPETE - Operational Programme for Competitiveness Factors (OPCF), by Portuguese National funds through "FCT - Fundação para a Ciência e a Tecnologia" under project «PTDC/AGR-AAM/101643/2008 NanoDC», by FP7-PEOPLE-IRSES-2010-269289ELECTROACROSS and by the research grant SFRH/BD/76070/2011. Prof. Jorge Varejão and Helena Silva are acknowledged for GC analysis and Sabrina Madsen for ICP analysis. NANO IRON, s.r.o. kindly provided NANOFER 25S samples. 


\section{REFERENCES}

Beckingham, B., Ghosh, U., 2011. Field-scale reduction of PCB bioavailability with activated carbon amendment to river sediments. Environ. Sci, Technol. 45, 1056710574.

Chang, Y., Achari, G., Langford, C., 2010. Effect of cocontaminants on the remediation of PCB-impacted soils by hydrogen peroxide. Pract. Period. Hazard. Toxic Radioact. Waste Manag. 14, 266-268.

Chen, X., Yao, X., Yu, C., Su, X., Shen, C., Chen, C., Huang, R., Xu, X., 2014. Hydrodechlorination of polychlorinated biphenyls in contaminated soil from an e-waste recycling area, using nanoscale zerovalent iron and $\mathrm{Pd} / \mathrm{Fe}$ bimetallic nanoparticles. Environ. Sci.Pollut. Res., 1-10.

Crane, R.A., Scott, T.B., 2012. Nanoscale zero-valent iron: Future prospects for an emerging water treatment technology. J. Hazard. Mater. 211-212, 112-125.

Fan, G., Cang, L., Qin, W., Zhou, C., Gomes, H.I., Zhou, D., 2013. Surfactants-enhanced electrokinetic transport of xanthan gum stabilized nano $\mathrm{Pd} / \mathrm{Fe}$ for the remediation of PCBs contaminated soils. Sep. Purif. Technol. 114, 64-72.

Ferreira, C., Jensen, P., Ottosen, L.M., Ribeiro, A.B., 2008. Preliminary treatment of MSW fly ash as a way of improving electrodialytic remediation, J. Environ. Sci. Healt A 43, 837-843.

Ferreira, C., Ribeiro, A., Ottosen, L., 2005. Effect of major constituents of MSW fly ash during electrodialytic remediation of heavy metals. Sep. Sci. Technol. 40, 2007-2019.

Gomes, H.I., Dias-Ferreira, C., Ottosen, L.M., Ribeiro, A.B., 2014a. Electrodialytic remediation of polychlorinated biphenyls contaminated soil with iron nanoparticles and two different surfactants. J.Colloid Interface Sci. 433, 189-195. 
Gomes, H.I., Dias-Ferreira, C., Ribeiro, A.B., 2013a. Overview of in situ and ex situ remediation technologies for PCB-contaminated soils and sediments and obstacles for full-scale application. Sci.. Total Environ. 445-446, 237-260.

Gomes, H.I., Dias-Ferreira, C., Ribeiro, A.B., Pamukcu, S., 2013b. Enhanced transport and transformation of zerovalent nanoiron in clay using direct electric current. Water Air Soil Poll. 224, 1-12.

Gomes, H.I., Fan, G., Mateus, E.P., Dias-Ferreira, C., Ribeiro, A.B., 2014b. Assessment of combined electro-nanoremediation of molinate contaminated soil. Sci. Total Environ. 493, 178-184.

Hansen, H.K., Ribeiro, A.B., Mateus, E.P., Ottosen, L.M., 2007. Diagnostic analysis of electrodialysis in mine tailing materials. Electrochim. Acta 52, 3406-3411.

He, F., Zhao, D., Paul, C., 2010. Field assessment of carboxymethyl cellulose stabilized iron nanoparticles for in situ destruction of chlorinated solvents in source zones. Water Res. 44, 2360-2370.

Jensen, S.F., 2009. PCB in Soil. The contamination of PCB in selected locations around Roskilde and Copenhagen. Report. Roskilde University, Denmark.

Jones, E.H., Reynolds, D.A., Wood, A.L., Thomas, D.G., 2010. Use of electrophoresis for transporting nano-iron in porous media. Ground Water 49, 172-183.

Kirkelund, G.M., Ottosen, L.M., Villumsen, A., 2009. Electrodialytic remediation of harbour sediment in suspension-Evaluation of effects induced by changes in stirring velocity and current density on heavy metal removal and pH. J. Hazard. Mater. 169, 685-690.

Kocur, C.M., Chowdhury, A.I., Sakulchaicharoen, N., Boparai, H.K., Weber, K.P., Sharma, P., Krol, M.M., Austrins, L.M., Peace, C., Sleep, B.E., O'Carroll, D.M., 2014. Characterization of nZVI mobility in a field scale test. Environ. Sci. Technol., DOI: 10.1021/es4044209. . 
Laumann, S., Micić, V., Lowry, G.V., Hofmann, T., 2013. Carbonate minerals in porous media decrease mobility of polyacrylic acid modified zero-valent iron nanoparticles used for groundwater remediation. Environ. Poll.179, 53-60.

Li, Y., Liang, F., Zhu, Y., Wang, F., 2013. Phytoremediation of a PCB-contaminated soil by alfalfa and tall fescue single and mixed plants cultivation. J. Soils Sediments 13, 925931.

Lima, A.T., Ottosen, L.M., Heister, K., Loch, J.P.G., 2012. Assessing PAH removal from clayey soil by means of electro-osmosis and electrodialysis. Sci.Total Environ. 435436, 1-6.

Liu, J., Chen, T., Qi, Z., Yan, J., Buekens, A., Li, X., 2014. Thermal desorption of PCBs from contaminated soil using nano zerovalent iron. Environ. Sci. Pollut.Res., 1-8.

Lopareva-Pohu, A., Pourrut, B., Waterlot, C., Garçon, G., Bidar, G., Pruvot, C., Shirali, P., Douay, F., 2011. Assessment of fly ash-aided phytostabilisation of highly contaminated soils after an 8-year field trial: Part 1. Influence on soil parameters and metal extractability. Sci. Total Environ. 409, 647-654.

Lowry, G., Johnson, K., 2004. Congener-specific dechlorination of dissolved PCBs by microscale and nanoscale zerovalent iron in a water/methanol solution. Environ. Sci. Technol. 38, 5208-5216.

Mehra, O.P., Jackson, M.L., 1960. Iron oxide removal from soils and clays by a dithionitecitrate system buffered with sodium bicarbonate. Clays Clay Miner. 7, 317-327.

Ottosen, L., Jensen, P., Kirkelund, G., Hansen, H., 2013. Electrodialytic remediation of different heavy metal-polluted soils in suspension. Water Air Soil Poll. 224, 1-10.

Pamukcu, S., Hannum, L., Wittle, J.K., 2008. Delivery and activation of nano-iron by DC electric field. J. Environ. Sci. Health A 43, 934-944. 
Pazos, M., Kirkelund, G.M., Ottosen, L.M., 2010. Electrodialytic treatment for metal removal from sewage sludge ash from fluidized bed combustion. J. Hazard. Mater. 176, 10731078.

Ram, N.M., McTiernan, L., Kinney, L., 2013. Estimating remediation costs at contaminated sites with varying amounts of available information. Remediation J. 23, 43-58.

Ribeiro, A.B., Mateus, E.P., Ottosen, L.M., Bech-Nielsen, G., 2000. Electrodialytic removal of $\mathrm{Cu}, \mathrm{Cr}$ and $\mathrm{As}$ from chromated copper arsenate-treated timber waste. Environ. Sci.Technol. 34, 784-788.

Summersgill, M., 2006. Remediation technology costs in the UK \& Europe; Drivers and changes from 2001 to 2005, in: Telford, T. (Ed.), Proceedings of the 5th International GeoEnviro Conference, June 2006, Cardiff.

Sun, T.R., Ottosen, L.M., Jensen, P.E., Kirkelund, G.M., 2012. Electrodialytic remediation of suspended soil - Comparison of two different soil fractions. J. Hazard. Mater. 203-204, 229-235.

Tosco, T., Petrangeli Papini, M., Cruz Viggi, C., Sethi, R., 2014. Nanoscale zerovalent iron particles for groundwater remediation: a review. J. Clean. Prod. 77, 10-21.

Varanasi, P., Fullana, A., Sidhu, S., 2007. Remediation of PCB contaminated soils using iron nano-particles. Chemosphere 66, 1031-1038.

Vasilyeva, G.K., Strijakova, E.R., Nikolaeva, S.N., Lebedev, A.T., Shea, P.J., 2010. Dynamics of PCB removal and detoxification in historically contaminated soils amended with activated carbon. Environ. Poll. 158, 770-777.

Wang, C.-B., Zhang, W., 1997. Synthesizing Nanoscale Iron Particles for Rapid and Complete Dechlorination of TCE and PCBs. Environ. Sci. Technol. 31, 2154-2156. 
Wang, Y., Zhou, D., Wang, Y., Wang, L., Cang, L., 2012. Automatic pH control system enhances the dechlorination of 2,4,4'-trichlorobiphenyl and extracted PCBs from contaminated soil by nanoscale $\mathrm{Fe}^{0}$ and $\mathrm{Pd} / \mathrm{Fe}^{0}$. Environ. Sci. Pollut. Res. 19, 448-457.

Wu, B.-Z., Chen, H.-Y., Wang, S.J., Wai, C.M., Liao, W., Chiu, K., 2012. Reductive dechlorination for remediation of polychlorinated biphenyls. Chemosphere 88, 757768.

Yang, G.C.C., Tu, H.C., Hung, C.-H., 2007. Stability of nanoiron slurries and their transport in the subsurface environment. Sep. Purif. Technol. 58 166-172.

Zhang, W., 2003. Nanoscale iron particles for environmental remediation: an overview. J. Nanoparticle Res. 5, 323-332.

Zhang, W., Elliott, D.W., 2006. Applications of iron nanoparticles for groundwater remediation. Remediation, 7-21.

Zhang, W., Wang, C.B., Lien, H.L., 1998. Treatment of chlorinated organic contaminants with nanoscale bimetallic particles. Catal. Today 40, 387-395.

Zhuang, Y., Ahn, S., Seyfferth, A.L., Masue-Slowey, Y., Fendorf, S., Luthy, R.G., 2011. Dehalogenation of polybrominated diphenyl ethers and polychlorinated biphenyl by bimetallic, impregnated, and nanoscale zerovalent iron. Environ. Sci. Technol. 45, 4896-4903. 